\title{
DESAIN DAN IMPLEMENTASI INTERLEAVED BOOST CONVERTER UNTUK POWER FACTOR CORRECTION MENGGUNAKAN PENGENDALI LOGIKA FUZZY
}

\author{
Mentari Putri Jati, Era Purwanto, Bambang Sumantri, Sutedjo dan Dimas Okky Anggriawan \\ Politeknik Elektronika Negeri Surabaya \\ Departemen Elektro \\ Kampus PENS, Jalan Raya ITS Sukolilo, Surabaya 60111, Indonesia \\ E-mail: mentaripj@gmail.com, era@pens.ac.id,bambang@pens.ac.id, sutedjo@pens.ac.id, \\ dimas@pens.ac.id
}

\begin{abstract}
Abstrak
Beberapa tahun terakhir terjadi peningkatan kebutuhan sumber daya tegangan dc. Kebanyakan dari rangkaian elektronika daya pada sumber tegangan dc menggunakan full wave rectifier. Pemasangan nilai kapasitor yang cukup besar sebagai filter pada full wave rectifier dapat menyebabkan bentuk gelombang arus input menjadi tidak sinusoidal (terdistorsi). Perbedaan bentuk gelombang tegangan dan arus input berpengaruh pada besar kecilnya faktor daya. Interleaved Boost Converter (IBC) yang difungsikan sebagai Power Factor Correction (PFC) dengan menggunakan metode pengendali logika fuzzy diterapkan pada sistem untuk mencapai faktor daya mendekati unity. IBC bekerja pada discontinuous conduction mode (DCM). Saat rectifier menyuplai beban yang bersifat resistif maka arus input memiliki bentuk gelombang yang sefasa dengan gelombang tegangan input. Simulasi dan implementasi alat menggunakan beban yang bervariasi. Hasilnya IBC sebagai PFC dapat memperbaiki faktor daya dari 0.67 menjadi 0.93 .
\end{abstract}

Kata kunci: Interleaved Boost Converter, Power Factor Correction, Discontinuous Conduction Mode, Pengendali Logika Fuzzy

\begin{abstract}
In recent years there is an increasing demand for closely regulated dc power supply. Most of the power electronic converters in these power supplies used full wave rectifier. Bulky filter capacitor in rectifier can effect non-sinusoidal input current waveform (distorted). The difference in voltage and current waveform affected the power factor system. Interleaved Boost Converter (IBC) as Power Factor Correction (PFC) with a fuzzy logic controller to be added in the system to achieved near to unity power factor. IBC operated in Discontinuous Conduction Mode (DCM). Power factor near to unity can be achieved while rectifier supplied resistive load, the waveform of load current through back to input source have the same form with the input voltage. Simulation and hardware implementation is used by varying loads. The experimental results with a variable load value of IBC as PFC can improve the power factor system from 0.67 to 0.93 .
\end{abstract}

Keywords: Interleaved Boost Converter, Power Factor Correction, Discontinuous Conduction Mode, Fuzzy Logic Controller

\section{Pendahuluan}

Karakteristik sumber tegangan searah (DC) membuatnya ideal untuk peralatan dan perangkat berdaya rendah. Dalam beberapa tahun terakhir terjadi peningkatan dalam penggunaan peralatan dengan sumber DC yang mengakibatkan bertambahnya perangkat nonlinier. Sebagian besar perangkat elektronika daya menggunakan full wave rectifier, yang bersifat nonlinier. Kehadiran perangkat

nonlinier mengakibatkan operasi faktor daya rendah dan distorsi harmonik yang tinggi. Peraturan Harmonik IEC 61000-3-2 mendefinisikan faktor daya dalam beberapa aplikasi, seperti alat portabel (kelas B), peralatan pencahayaan (kelas C), komputer (kelas D) dll [1], [2]. 
Harmonisa juga dapat menurunkan kualitas sistem tenaga listrik yang dapat menyebabkan dampak negatif terhadap peralatan - peralatan lain pada suatu instalasi [3].

Perbaikan faktor daya diperlukan dalam perangkat ini untuk memenuhi standar harmonik, umur perangkat yang lebih lama serta kelancaran pengoperasian perangkat lain dalam sistem. Keuntungan lain dari PFC termasuk peningkatan kapasitas sistem kelistrikan, berkurangnya rugi - rugi daya dalam sistem distribusi, pengurangan tegangan turun yang menyebabkan panas berlebih serta kegagalan prematur pada kasus beban motor dan peralatan induktif lainnya [1].

Untuk mencapai faktor daya mendekati satu tanpa sistem pengendali, konverter boost konvensional dengan operasi mode konduksi terputus banyak digunakan oleh industri [4].

Penggunaan interleaved boost converter (IBC) telah menyebabkan aliran arus paralel melalui induktor yang menghasilkan penggunaan induktor dan kapasitor dengan pembebanan yang lebih rendah. Dengan mengoperasikan IBC pada rasio siklus tegangan $50 \%$, tegangan dan arus riak telah sangat berkurang.

\section{Studi Pustaka}

IEEE 519-2014 digunakan untuk mengatur dan menerapkan batas harmonik dalam sistem tenaga. Arus harmonisa ini juga menyebabkan peningkatan rugi - rugi daya dan peningkatan temperatur di berbagai perangkat elektromagnetik (motor, transformer, dll.). Standar yang direkomendasikan menetapkan praktek dengan tujuan untuk mendesain sistem kelistrikan yang mencakup beban linier dan nonlinier [4].

Rangkaian perbaikan faktor daya tipe aktif biasanya menggunakan pencacahan catu daya untuk mengurangi harmonisa arus input bolak - balik (AC) dan mengatur tegangan output searah (DC). Topologi konverter penaik tegangan (boost) terus digunakan dalam berbagai aplikasi AC ke DC dan sebaliknya. Konverter tipe boost merupakan rangkaian perbaikan faktor daya aktif paling populer. Menurut bentuk gelombang arus induktor kontinu atau tidak, mode operasi konverter perbaikan faktor daya boost dikelompokkan ke dalam mode konduksi arus kontinu (CCM), mode konduksi arus kritis (CRM) dan mode konduksi arus diskontinyu/terputus (DCM). CRM dan DCM konverter boost PFC memiliki keuntungan seperti arus nol saat saklar terhubung dan tidak ada arus balik dioda. Frekuensi pensaklaran/switching pada konverter perbaikan faktor daya CRM boost berubah - ubah. Sedangkan desain induktor dan filter EMI lebih sulit. Selain itu, konverter perbaikan faktor daya DCM boost dioperasikan dalam frekuensi pensaklaran konstan.

Interleaved boost converter (IBC) dengan switching tegangan-nol (ZVS) dan switching arus-nol (ZCS) juga digunakan sebelumnya untuk mengurangi riak arus, dan riak tegangan. Sistem ini juga memiliki kelemahan dari peningkatan jumlah komponen serta pengendalian yang rumit. Kebaruan pendekatan kontrol yang didasarkan pada peraturan minimisasi fungsi energi diusulkan untuk beroperasi dengan respons dinamis yang lebih cepat. Pada kasus ini memiliki kelemahan kompleksitas tinggi. Dengan menggunakan pengendali logika fuzzy, output yang diinginkan merupakan peningkatan faktor daya dan pengurangan riak arus [1], [5].

\section{Metode}

\section{A. Prinsip Kerja Interleaved Boost Converter (IBC)}

Konverter yang diusulkan seperti pada gambar 1 bahwa interleaved boost converter (IBC) merupakan dua rangkaian konverter boost ysng dipasang paralel. Rangkaian dengan induktor L1, dioda D1, saklar S1 membentuk rangkaian boost dan induktor L2, dioda D2, saklar S2 dari rangkaian paralel boost. Kapasitor Co digunakan untuk menjaga keluaran tegangan riak dan $\mathrm{R}$ adalah beban sistem.

Konverter boost konvensional telah digunakan untuk rangkaian perbaikan faktor daya aktif. Namun, rangkaian baru ini menggunakan konverter dual boost yang terhubung secara paralel. Induktor L1 dan saklar S1 digunakan sebagai rangkaian perbaikan faktor daya sedangkan induktor L2 dan saklar S2 menggantikan filter aktif untuk meningkatkan kualitas arus input yang mengandung harmonisa. Filter aktif juga mengurangi rugi - rugi akibat pensaklaran pada rangkaian. Analisis rangkaian IBC berdasarkan seperti konverter boost tunggal dalam mode DCM.

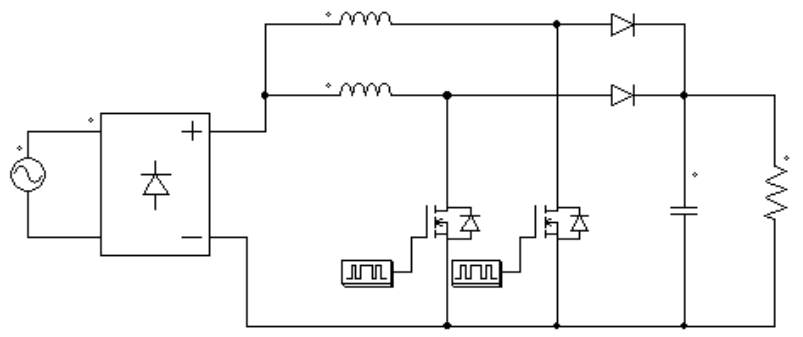

Gambar 1: Interleaved boost converter

1. Saklar terhubung dan dioda bias mundur [6] 


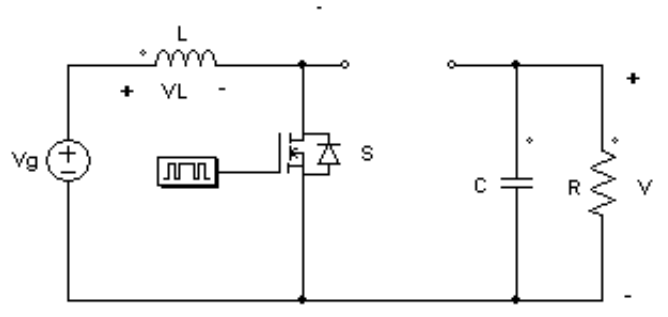

(a): Selama $0<\mathrm{t}<\mathrm{D} 1 \mathrm{Tg}$

$$
\begin{aligned}
& v_{L}(t)=v_{g} \\
& i_{C}(t)=\frac{-v(t)}{R}
\end{aligned}
$$

2. Saklar tak terhubung dan dioda bias maju [6]

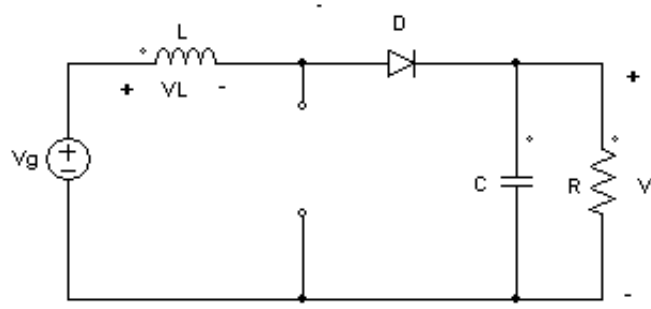

(b): Selama D1Tg $<$ t $<(\mathrm{D} 1+\mathrm{D} 2) \mathrm{Tg}$

$$
\begin{aligned}
& v_{L}(t)=v_{g}-v(t) \\
& i_{L}(t)=i_{C}(t)+\frac{v(t)}{R} \\
& i_{C}(t)=i_{L}(t)-\frac{v(t)}{R}
\end{aligned}
$$

3. Saklar tak terhubung dan dioda bias mundur [6]

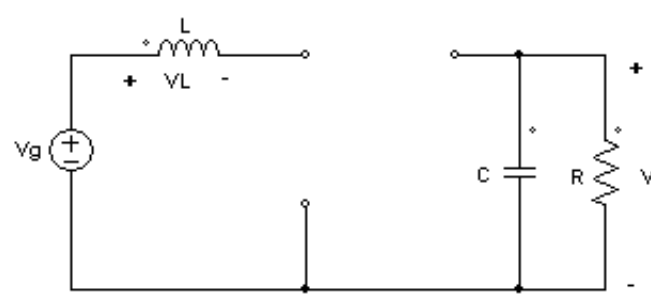

(c): Selama $(\mathrm{D} 1+\mathrm{D} 2) \mathrm{Tg}<\mathrm{t}<\mathrm{Tg}$

Gambar 2: Prinsip kerja Boost Converter

$$
\begin{aligned}
& v_{L}(t)=0 \\
& i_{L}(t)=0 \\
& i_{C}(t)=\frac{-v(t)}{R}
\end{aligned}
$$

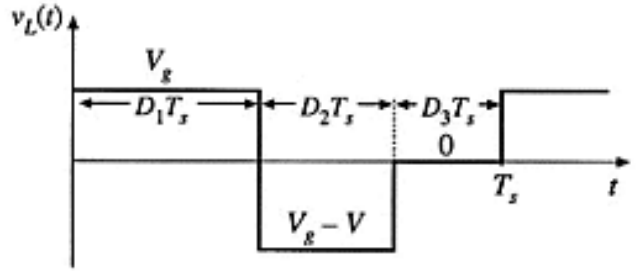

Gambar 3: Gelombang tegangan induktor VL(t) converter boost mode konduksi arus terputus/diskontinyu

Persamaan (1), (3) dan (5) digunakan untuk menggambar gelombang tegangan induktor seperti pada gambar 3. Dengan tegangan per detik seimbang, gelombang ini tidak mengandung komponen DC ketika konverter beroperasi pada kondisi stabil [6], [7].

(a)

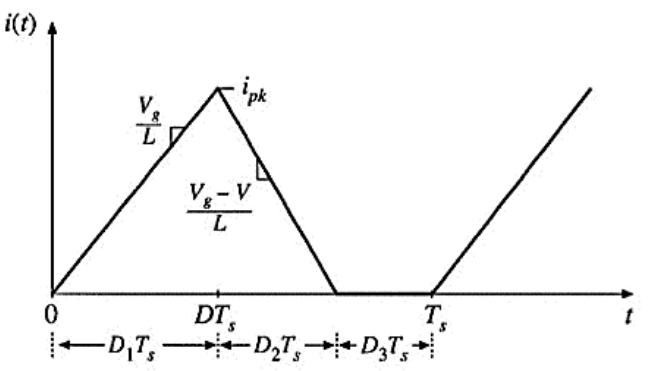

(b)

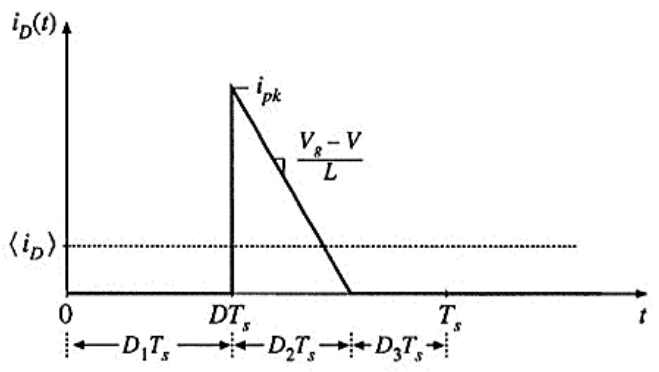

Gambar 4: Gelombang konverter boost (a) arus induktor i(t) (b) arus dioda $\mathrm{iD}(\mathrm{t})$

Pada rangkaian perbaikan faktor daya, rs dihitung dari $\mathrm{Vg}$ dan is setiap satu kali periode pensaklaran.

$r_{s}=\frac{v_{g}}{i_{s}}$

$i_{s}(t)=\frac{\frac{1}{2} t\left(i_{L}(t)\right) D T}{R}$

Berdasarkan gambar 4(a) saat periode $\mathrm{D}_{1} \mathrm{~T}_{\mathrm{s}}$

$i_{L}(t)=\frac{v_{g}}{L} D T$

Maka, (10) disubstitusikan ke (9)

Dimana, $\mathrm{VL}=$ tegangan induktor; $\mathrm{Vg}=$ tegangan catu daya; $\mathrm{V}=$ tegangan beban; $\mathrm{iL}=$ arus induktor; $\mathrm{ic}=$ arus kapasitor. 
$i_{s}(t)=\frac{\frac{1}{2} t\left(\frac{v_{g}}{L} D T\right) D T}{R}$

$i_{s}(t)=\frac{v_{g} D^{2} T}{2 L}$

Persamaan (11) disubstitusikan ke (8)

$$
\begin{aligned}
& r_{s}(t)=\frac{v_{g}}{\frac{v_{g} D^{2} T}{2 L}} \\
& r_{s}(t)=\frac{2 L}{D^{2} T}
\end{aligned}
$$

Dimana, $r s=$ resistansi input; is $=$ arus input; $\mathrm{iL}=$ arus induktor; $\mathrm{D}=$ persen siklus tegangan; $\mathrm{T}=$ waktu; $\mathrm{R}=$ beban; $\mathrm{Vg}=$ tegangan catu daya; $\mathrm{L}=$ induktor;

Karena nilai L, D dan T tidak berubah, maka resistansi input bernilai konstan. Berdasarkan (8) dengan tegangan input sinusoidal dan resistansi input rs konstan, maka arus is mengikuti bentuk gelombang input sinusoidal sehingga beban bersifat resistif yang mempunyai faktor daya mendekati satu.

\section{B. Prinsip Kerja Interleaved Boost Converter (IBC)}

Komponen utama konverter merupakan pada desain induktor karena akan berpengaruh pada arus input dan output. Konverter perbaikan faktor daya yang digunakan dengan mengacu ketentuan sebagai berikut:

- Tegangan input : 28.82 volt

- Tegangan output : 48 volt

- $\quad$ Efisiensi

$: 90 \%$

- Frekuensi

: $40 \mathrm{kHz}$

Maka, desain induktor konverter:

$$
L_{\min }=\frac{D(1-D)^{2} R}{2 f}
$$

\section{Pengendali Logika Fuzzy}

Pengendali logika fuzzy merupakan alternatif sistem kendali modern yang tidak memerlukan model matematis dari suatu sistem. Pengendali ini tetap efektif karena memiliki respon sistem yang stabil [3].

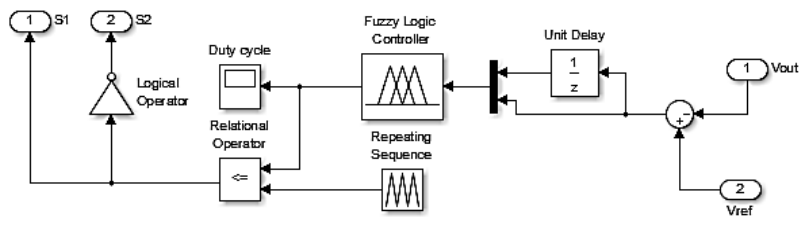

Gambar 5: Rangkaian pengendali logika fuzzy di Simulink
TABLE I

ATURAN DASAR FUZZY

\begin{tabular}{|l|l|l|l|l|l|}
\hline D-ElE & BN & SN & Z & SP & BP \\
\hline BN & NVB & NVB & NVB & NB & Z \\
\hline SN & NVB & NM & NS & Z & PB \\
\hline Z & NVB & NS & Z & PS & PVB \\
\hline SP & NB & Z & PS & PM & PVB \\
\hline BP & Z & PB & PVB & PVB & PVB \\
\hline
\end{tabular}

IBC membutuhkan pengontrol untuk menstabilkan tegangan output. Perancang pengontrol dalam simulasi loop tertutup dengan tegangan input dari rectifier. Rangkaian simulasi loop tertutup dari IBC ditunjukkan pada gambar 5. Dengan menggunakan fungsi keanggotaan segitiga dalam model fuzzy Mamdani, dapat menghubungkan setiap variabel, misalnya kesalahan dan perubahan kesalahan dalam aturan untuk memberikan output.

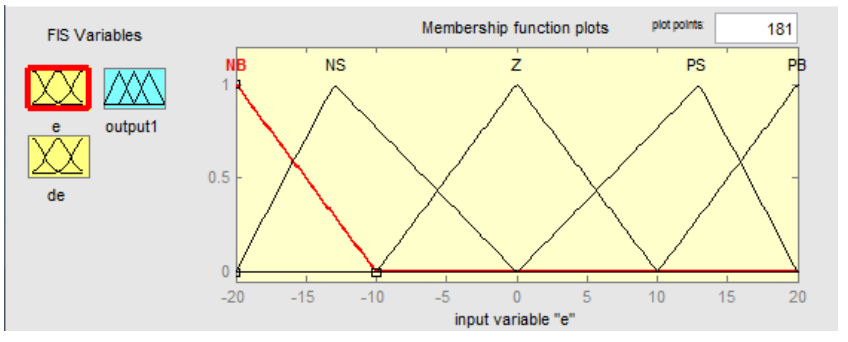

(a)

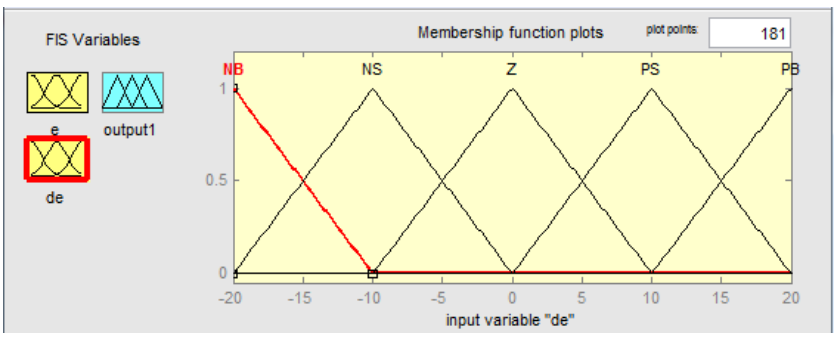

(b)

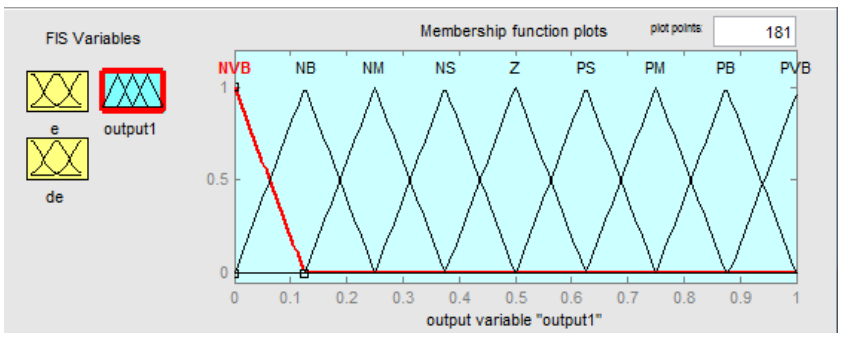

(c)

Gambar 6: Variabel fuzzy (a) input error (b) input delta error (c) output 


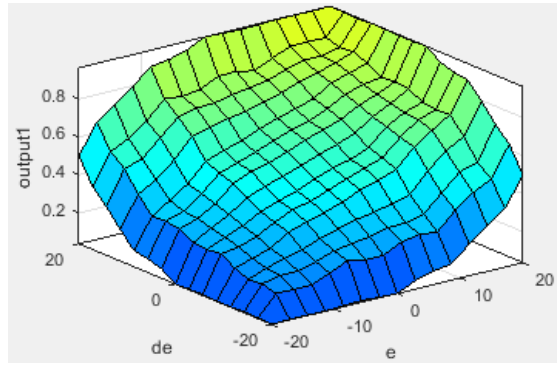

Gambar 7: Surface variabel fuzzy

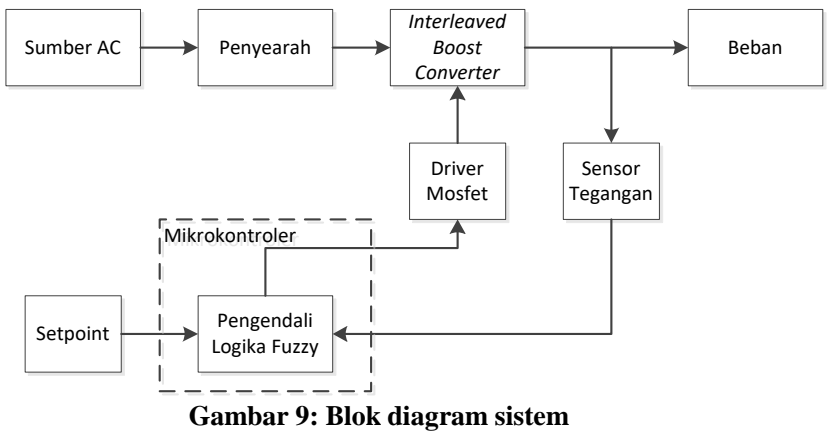

Tabel 1 menunjukkan aturan fuzzy yang akan memberikan perubahan nilai output yang bervariasi. Editor FIS digunakan untuk memasukkan variabel dalam fuzzy dan ada fungsi keanggotaan segitiga

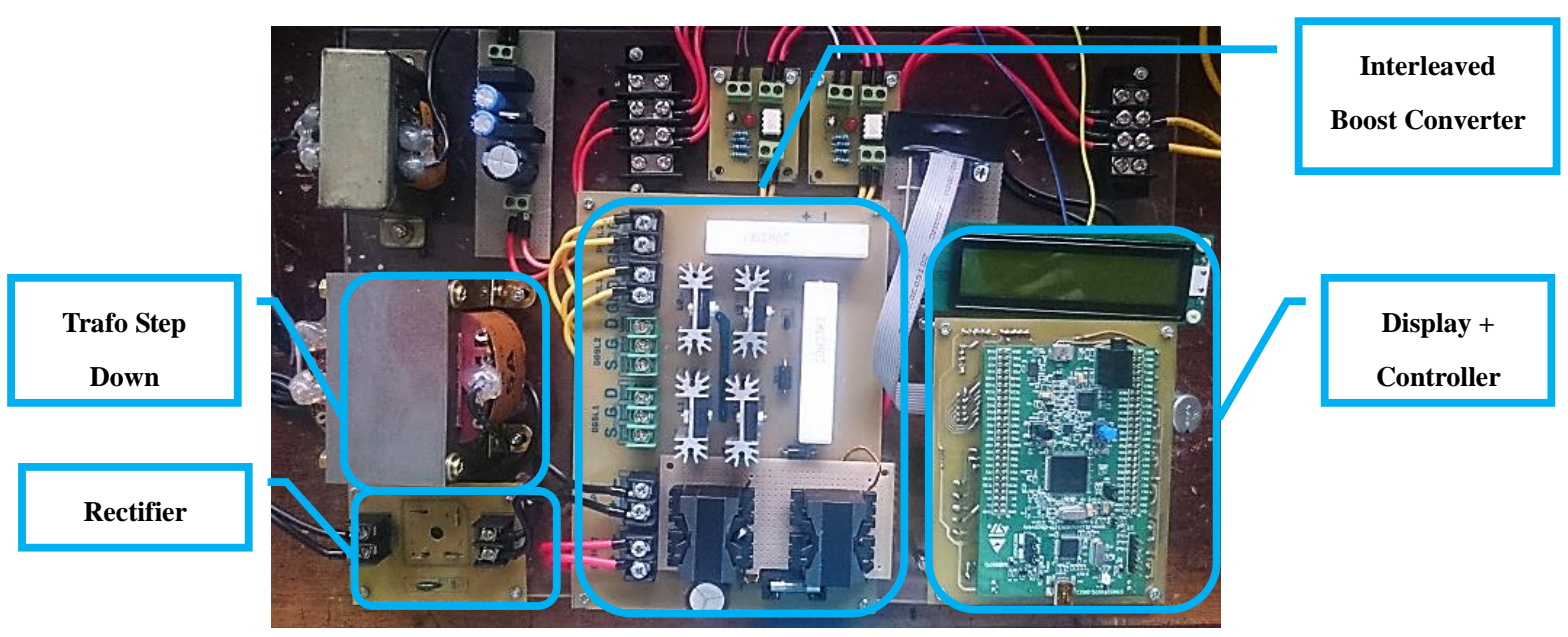

Gambar 8: Hardware sistem

\section{Hasil dan Pembahasan}

Berdasarkan desain, parameter sistem ditunjukkan pada Tabel 2 untuk merancang IBC sebagai PFC dan regulator tegangan. Selain itu, perancangan sistem perangkat keras ditunjukkan pada Gambar 10 yang sesuai dengan parameter simulasi. Percobaan secara simulasi dan implementasi dilakukan dalam 2 tahap yaitu pengujian sistem tanpa dan dengan konverter perbaikan faktor daya.

\section{TABLE II}

PARAMETER SISTEM
\begin{tabular}{|l|l|}
\hline Parameter & Value \\
\hline Input voltage rectifier & 20.66 Volt \\
\hline Input voltage IBC & 18.94 Volt \\
\hline Output voltage & $48 \mathrm{Volt}$ \\
\hline Switching frequency & $40 \mathrm{kHz}$ \\
\hline Inductor & $45 \mu \mathrm{H}$ \\
\hline Switch & $\mathrm{MOSFET} \mathrm{IRFP460}$ \\
\hline Bulk capacitor & $1 \mu \mathrm{F}$ \\
\hline Output capacitor & $330 \mu \mathrm{F}$ \\
\hline
\end{tabular}

TABLE III

EFISIENSI KONVERTER

\begin{tabular}{|l|l|l|l|l|l|}
\hline Vs & Is & D & Vo & Io & $\eta$ \\
\hline
\end{tabular}

\begin{tabular}{|c|c|c|c|c|c|}
\hline (Volt) & (A) & & (Volt) & (A) & $(\%)$ \\
\hline 5 & 0.68 & \multirow{6}{*}{40} & 10.6 & 0.3 & 93.5 \\
\hline 10 & 1.36 & & 21.11 & 0.58 & 90.0 \\
\hline 15 & 1.97 & & 31.68 & 0.85 & 91.1 \\
\hline 20 & 2.58 & & 41.9 & 1.15 & 93.4 \\
\hline 25 & 3.22 & & 52.4 & 1.4 & 91.1 \\
\hline 28.3 & 3.6 & & 59 & 1.58 & 91.5 \\
\hline
\end{tabular}

A. Simulasi Matlab

Simulasi Matlab menggunakan parameter sistem yang sama dengan eksperimen agar dapat dibandingkan hasil keduanya. Blok diagram simulasi Matlab ditunjukkan pada Gambar 7. Pada sistem catu daya dc dengan kapasitor filter yang besar menghasilkan tegangan keluaran dc murni tanpa riak tetapi memiliki gelombang tegangan dan arus input tidak sefasa.

Gelombang arus input berbentuk tidak sinus yang diakibatkan nilai fundamental bercampur arus dari efek pengisian dan pembuangan kapasitor. Perbedaan bentuk gelombang tegangan dan arus menyebabkan faktor daya sisi input tidak sesuai standar yang berlaku $(<85 \%)$ seperti yang ditunjukkan pada Gambar 8. Bentuk gelombang tegangan input berupa sinusoidal dan arus input terdistorsi. 
Penggunaan filter kapasitor sisi output yang besar dapat dieliminasi dengan konverter perbaikan faktor daya berupa IBC. Oleh karena itu, sistem menggunakan IBC tidak memerlukan kapasitor filter yang besar untuk menghasilkan tegangan dan arus input pada fase yang sama. Gelombang arus pada sistem dengan IBC terlihat dalam simulasi Matlab yang ditunjukkan pada Gambar 9.

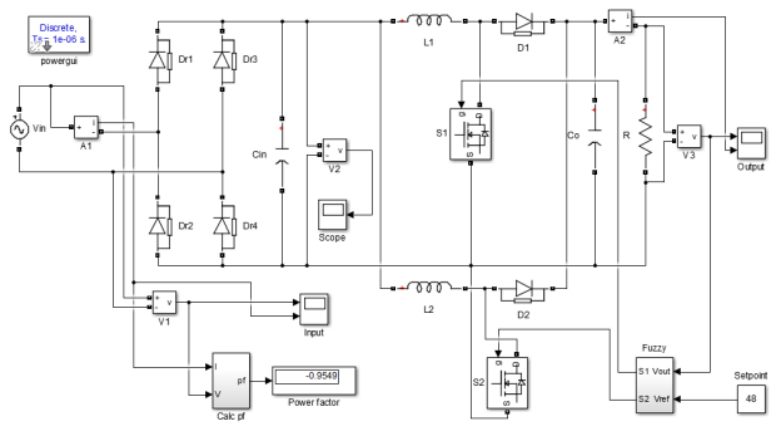

Gambar 10: Rangkaian sistem pada simulasi Simulink/Matlab
A. Implementasi Alat

Untuk mengevaluasi dan membuktikan keunggulan konverter perbaikan faktor daya pada aplikasi ini, alat percobaan telah dibangun.

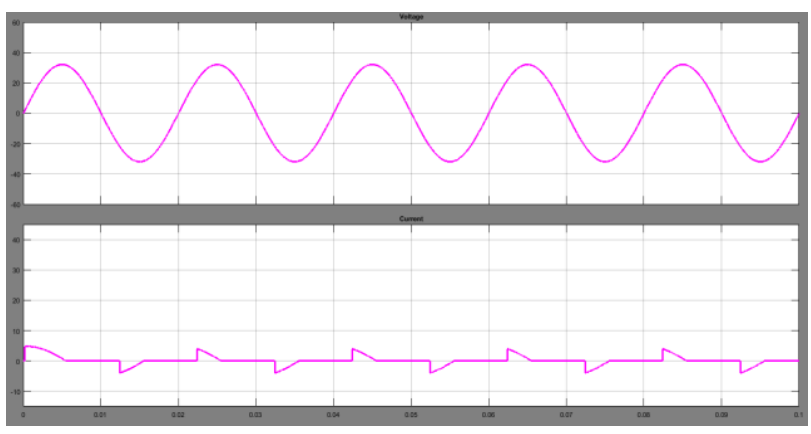

Gambar 11:

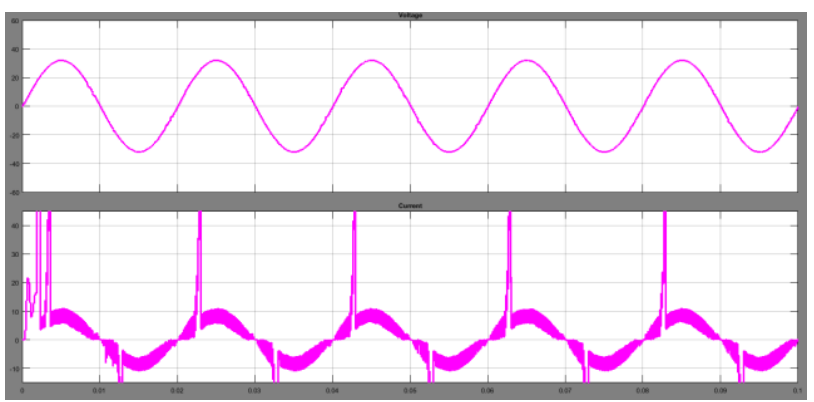

Gambar 12:

Pengujian alat menggunakan variasi beban resistif berupa lampu 220 volt $100 \mathrm{~W}$ dipasang paralel. Variasi beban ada tiga tipe berdasarkan jumlahnya yaitu paralel 3, 4 dan 5 lampu $100 \mathrm{~W}$. Dengan beban resistif diparalel maka pada tiap pengujian dengan beban yang berbeda menghasilkan arus input dan output berbeda pula. Pengujian kinerja konverter perbaikan faktor daya mempunyai efisiensi rata - rata 91.77\% dengan tegangan input variatif seperti pada

tabel 3.

TABLE IV

FAKTOR DAYA SISTEM TANPA IBC (RECTIFIER TANPA FILTER

\begin{tabular}{|l|l|l|l|l|l|l|}
\multicolumn{1}{|c|}{ KAPASITOR $)$} \\
\hline Beban & $\begin{array}{l}\mathbf{V}_{\text {inAC }} \\
(\mathbf{V})\end{array}$ & $\begin{array}{l}\text { Vout } \\
(\mathbf{V})\end{array}$ & $\begin{array}{l}\text { Iout } \\
(\mathbf{A})\end{array}$ & $\begin{array}{l}\mathbf{l i n}_{\mathrm{AC}} \\
(\mathbf{A})\end{array}$ & $\mathbf{P F}$ & $\mathbf{D P F}$ \\
\hline
\end{tabular}

TABLE V

FAKTOR DAYA SISTEM TANPA IBC (RECTIFIER DENGAN FILTER

\begin{tabular}{|l|l|l|l|l|l|l|l|}
\hline Beban & $\begin{array}{l}\mathbf{V}_{\text {inAC }} \\
(\mathbf{V})\end{array}$ & $\begin{array}{l}\text { Vout } \\
(\mathbf{V})\end{array}$ & $\begin{array}{l}\text { Iout } \\
(\mathbf{A})\end{array}$ & $\begin{array}{l}\mathbf{I i n}_{\text {AC }} \\
(\mathbf{A})\end{array}$ & PF & DPF & DF \\
\hline $\begin{array}{l}5 \\
\text { lampu }\end{array}$ & 55.8 & 48 & 0.50 & 0.85 & 0.67 & 1 & 0.68 \\
\hline
\end{tabular}

TABLE VI

ARUS HARMONISA TANPA IBC (RECTIFIER DENGAN FILTER

KAPASITOR)

\begin{tabular}{|l|l|l|l|l|l|l|}
\hline \multirow{2}{*}{ Beban } & \multicolumn{5}{|l|}{ Harmonisa } \\
\cline { 2 - 7 } & $\mathbf{1}$ & $\mathbf{3}$ & $\mathbf{5}$ & $\mathbf{7}$ & $\mathbf{9}$ & $\mathbf{1 1}$ \\
\hline 5 lampu & 0.59 & 0.50 & 0.33 & 0.16 & 0.04 & 0.03 \\
\hline
\end{tabular}

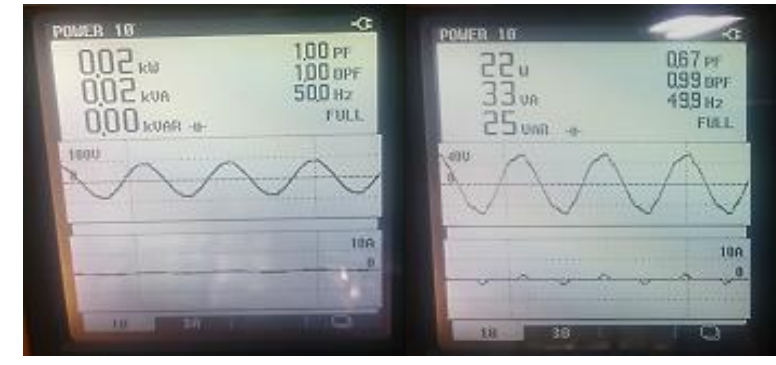

(a)

(b)

Gambar 13: Faktor daya tanpa IBC (a) Rectifier tanpa filter kapasitor (b) Rectifier dengan filter kapasitor

Pengujian sistem tanpa IBC dengan parameter yang diamati adalah gambar gelombang tegangan dan arus input, besarnya THD dan power faktor. Pengujian ini menggunakan Power Harmonic Analyzer 43B. Pengujian dilakukan dengan beban lampu 220V, 100W. Percobaan pertama dengan rectifier tanpa filter kapasitor dan percobaan kedua dengan rectifier diparalel filter kapasitor. Data hasil pengujian ditunjukkan pada Tabel 4 dan 5.

Untuk perhitungan DF (Distortion Factor) dengan cara menghitung arus tiap komponen harmonisa ganjilnya. Nilai DF menentukan ukuran suatu gelombang yang terdistorsi dengan membandingkan arus fundamental dan arus harmonisa yg terukur. Pada beban 5 buah lampu $220 \mathrm{~V} 100 \mathrm{~W}$ yang diparalel, Tabel 6 menunjukkan data arus harmonisa ganjil. Maka nilai DF untuk beban 5 lampu 220 V 100 W 
tanpa IBC:

$$
\begin{aligned}
& D F_{5}=\frac{0.59}{\sqrt{0.59^{2}+0.5^{2}+0.33^{2}+0.16^{2}+0.04^{2}+0.03^{2}}} \\
& D F_{5}=0.68
\end{aligned}
$$

TABLE VII

FAKTOR DAYA SISTEM DENGAN IBC DAN BEBAN BERVARIASI

\begin{tabular}{|l|l|l|l|l|l|l|l|}
\hline Beban & $\begin{array}{l}\mathbf{V}_{\text {inAC }} \\
(\mathbf{V})\end{array}$ & $\begin{array}{l}\text { Vout } \\
(\mathbf{V})\end{array}$ & $\begin{array}{l}\text { Iout } \\
(\mathbf{A})\end{array}$ & $\begin{array}{l}\mathbf{I i n}_{\mathrm{AC}} \\
(\mathbf{A})\end{array}$ & $\mathbf{P F}$ & $\mathbf{D P F}$ & $\mathbf{D F}$ \\
\hline $\begin{array}{l}5 \\
\text { lampu }\end{array}$ & 20.66 & 48.1 & 0.50 & 1.30 & 0.93 & 1 & 0.94 \\
\hline $\begin{array}{l}4 \\
\text { lampu }\end{array}$ & 20.66 & 48.1 & 0.40 & 1.09 & 0.91 & 1 & 0.91 \\
\hline $\begin{array}{l}3 \\
\text { lampu }\end{array}$ & 20.66 & 48.1 & 0.30 & 0.61 & 0.90 & 1 & 0.82 \\
\hline \multicolumn{7}{c|}{ TABLE VIII }
\end{tabular}

ARUS HARMONISA SISTEM DENGAN IBC

\begin{tabular}{|l|c|c|c|c|c|c|}
\hline \multirow{2}{*}{ Beban } & \multicolumn{7}{|c|}{ Harmonisa } \\
\cline { 2 - 7 } & $\mathbf{1}$ & $\mathbf{3}$ & $\mathbf{5}$ & $\mathbf{7}$ & $\mathbf{9}$ & $\mathbf{1 1}$ \\
\hline 5 lampu & 1.22 & 0.43 & 0.03 & 0.08 & 0.00 & 0.02 \\
\hline 4 lampu & 1.00 & 0.42 & 0.04 & 0.07 & 0.02 & 0.01 \\
\hline 3 lampu & 0.49 & 0.29 & 0.16 & 0.07 & 0.02 & 0.03 \\
\hline
\end{tabular}

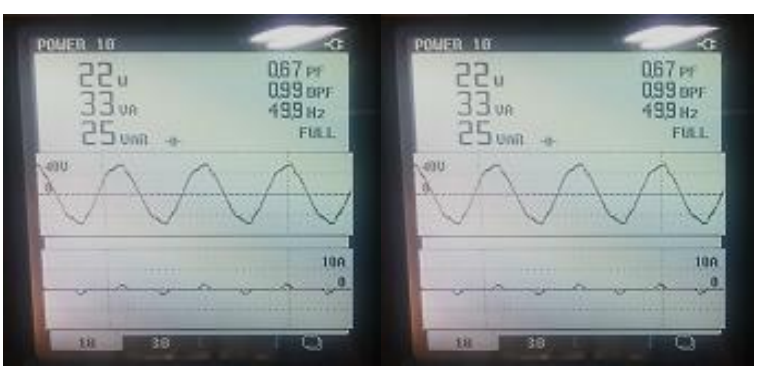

(a)

(b)

Gambar 14: Faktor daya sistem (a) tanpa IBC (b) dengan IBC

Selanjutnya, pengujian sistem dengan IBC tanpa filter kapasitor output yang besar. Percobaan dilakukan dengan rectifier tanpa filter kapasitor. Data hasil pengujian ditunjukkan pada Tabel 7 dan 8. Faktor daya sistem ketiga beban mempunyai rata - rata 0.91 . Berdasarkan arus harmonisa ganjil yang terukur seperti pada Tabel 8, nilai DF untuk beban 3,4 dan 5 lampu $220 \mathrm{~V} 100 \mathrm{~W}$ tanpa IBC:

$$
\begin{aligned}
& D F_{5}=\frac{1.22}{\sqrt{1.22^{2}+0.43^{2}+0.03^{2}+0.08^{2}+0.02^{2}}} \\
& D F_{5}=0.94 \\
& D F_{4}=\frac{1.22}{\sqrt{1^{2}+0.42^{2}+0.04^{2}+0.07^{2}+0.02^{2}+0.01^{2}}} \\
& D F_{4}=0.91
\end{aligned}
$$

$$
\begin{aligned}
& D F_{3}=\frac{0.49}{\sqrt{0.49^{2}+0.29^{2}+0.16^{2}+0.07^{2}+0.02^{2}+0.03^{2}}} \\
& D F_{3}=0.82
\end{aligned}
$$

\section{Kesimpulan}

Rangkaian konverter perbaikan faktor daya menggunakan mode konduksi terputus interleaved boost converter (IBC) telah disajikan baik simulasi maupun eksperimental. Kompensasi faktor daya yang diusulkan bernilai mendekati satu. Hasil simulasi di Matlab/Simulink, IBC sebagai rangkaian perbaikan faktor daya dengan pengendali logika fuzzy dapat meningkatkan faktor daya (pf) menjadi 0.94. Untuk mengevaluasi desain IBC, dibuktikan dalam implementasi alat dengan berbagai beban dapat mencapai perbaikan faktor daya paling baik dari 0.67 ke 0.93. Hasil kompensasi harmonisa menggunakan IBC dapat mengurangi THDi dari $72.3 \%$ menjadi $33.4 \%$.

\section{References}

[1] N. Shaji and D. S. K, "Fuzzy Controlled Power Factor Correctionin AC/DC Interleaved Boost Converter," Int. Conf. Circuit, Power Comput. Technol. [ICCPCT], pp. 165-173, 2016.

[2] IEEE Power and Energy Society, "IEEE Recommended Practice and Requirements for Harmonic Control in Electric Power Systems IEEE Power and Energy Society," IEEE Stand. 519-2014, vol. 2014, 2014.

[3] I. N. Dani, U. Ba'afai, and M. Ramli, "Desain Filter Aktif dengan Skema Fuzzy Logic Controller untuk Mereduksi Harmonisa," J. Rekayasa Elektr., vol. 11, no. 2, 2014.

[4] D. Garinto, "Interleaved Boost Converter System for Unity Power Factor Operation," 2007 Eur. Conf. Power Electron. Appl., vol. 1, no. c, pp. 1-7, 2007.

[5] T. Ajith Bosco Raj and R. Ramesh, "Improved Parallel Boost Power Converter for Power Factor Correction," Res. J. Appl. Sci. Eng. Technol., vol. 7, no. 23, pp. 4986-4998, 2014.

[6] M. H. Rashid, Power Electronics Handbook. Butterworth-Heinemann, 2017. Electronics, vol. 2. 2000. 